\title{
The Persistent Reduction in Poverty from Filing a Tax Return Online Appendix
}

\author{
Shanthi P. Ramnath Patricia K. Tong
}




\section{A Appendix, For Online Publication}

\section{A.1 Placebo Tests}

To alleviate concerns that the discontinuous jump in filing might occur in other parts of the income distribution or in other tax years, we conduct several different placebo tests at different points in the income distribution and in other tax years. The first test is to impose artificial eligibility thresholds at $\$ 2,000$ and $\$ 4,000$ and re-estimate our baseline specification. Similar to our main results, these regressions use $2007 \mathrm{~W}-2$ wages as the running variable. We do not estimate the probability of filing a 2007 return to be stastistically different from zero when eligibility is defined either by having wages above $\$ 2,000$ or by having wages above $\$ 4,000$. In addition, we do our RD estimates estimating the effect of eligibility on the outcome variables are generally not statistically different from zero when eligibility is defined using the $\$ 2,000$ and $\$ 4,000$ cutoffs. Figures A1 and A2 further demonstrate that there generally insignificant breaks in outcomes variables at the placebo cutoffs.

As a second placebo test, we use 2006 Form W-2 wage earnings as the running variable instead of 2007 Form W-2 wage earnings and redo our analysis. The RD estimates results are generally statistically significant when we replace the running variable with 2006 wage earnings. When the estimates are statistically significant, they are signed in the opposite direction compared to those from the main analysis as demonstrated in Figure A3.

As a third placebo test, we use estimate the RD without observations at the cutoff of $\$ 3,000$ as an additional robustness check which is the methodology used in Almond et al. (2011). In addition, we estimate the RD when we drop observations within a narrow band of the $\$ 3,000$ cutoff. We find that the estimated effect of stimulus eligiblity on filing a 2007 tax return ranges between 1.8 and 2.1 percentage points, which contains our point estimate of 2.2 from our main analysis (see Table A18). As a result, we do not find that bunching at $\$ 3,000$ is driving our results.

For a fourth placebo test, we construct a sample of long term non-filers for a different time period and check for a significant jump in the probability of filing around the $\$ 3,000$ cutoff. Specifically, we estimate an RD using the probability of filing a 2005 return as the outcome variable among the population of individuals who were non-filers in 2003 and $2004 .{ }^{1}$ We find that having wage earnings above $\$ 3,000$ has a small, marginally significant

\footnotetext{
${ }^{1}$ Similar to our baseline data construction, we restricted the sample to individuals aged 25-60 in 2003, with social security numbers, and were not claimed as dependents. In addition, we dropped filers with positive tax liability reported on their 2005 tax returns.
} 
0.5 percentage point effect on the probability of filing in 2005 . The reduced form estimates for the the outcome variables are generally statistically insignificant, or when significant, very small in magnitude. Figure A4 depicts the reduced form pictures that are analogous to the set of figures shown in the main analysis. These Figures show that the outcomes variables generally have little to no break at the $\$ 3,000$ cutoff.

Overall, we find no evidence of large significant increases in the probability of filing around \$3,000 in other tax years or at different points of the income distribution in 2007. These placebo test results support our conclusion that the discontinuous jump in filing a 2007 return around the $\$ 3,000$ cutoff is a result of the ESA08.

\section{A.2 Relaxing Sample Restrictions}

To demonstrate that our sample restrictions are not driving our main results, we redo our analysis with the sample of workers with wages below \$6,000 and are aged 25-60 in 2005. We eliminate the sample restrictions that better target individuals who would be the most affected by the stimulus rebate, including our restrictions to limit to non-filers in 2005 and 2006, individuals with income below the 2005-2007 filing thresholds, and those without social security income. Our results in Table A17 show that the results with the broader sample are similar to those presented in the main analysis. 


\section{References}

Almond, Douglas, Jr. Joseph J. Doyle, Amanda E. Kowalski, and Heidi Williams, "The Role of Hospital Heterogeneity in Measuring Marginal Returns to Medical Care: A Reply to Barreca, Guldi, Lindo, and Waddell," The Quarterly Journal of Economics, 2011, 126 (4), 2125-2131. 
Table A1: Balance Tests

\begin{tabular}{l|ccc}
\hline \hline & Age in 2004 & File in 2004 & Claim EITC in 2004 \\
\hline Stimulus Eligible & $0.143^{*}$ & 0.001 & $-0.008^{* * *}$ \\
& $(0.083)$ & $(0.003)$ & $(0.003)$ \\
Observations & $1,246,808$ & $1,246,808$ & $1,246,808$ \\
Bandwidth & 757.2 & 1154 & 613.8 \\
\hline \hline & & & \\
& Work in 2004 & Work in 2005 & Work in 2006 \\
\hline Stimulus Eligible & $-0.013^{* *}$ & $-0.009 * *$ & -0.005 \\
& $(0.005)$ & $(0.004)$ & $(0.004)$ \\
Observations & $1,246,808$ & $1,246,808$ & $1,246,808$ \\
Bandwidth & 470.1 & 748.0 & 736.0 \\
& & & \\
\hline \hline & & & \\
& Wages 2004 & Wages 2005 & Wages 2006 \\
\hline Stimulus Eligible & $-66.174 * *$ & $-27.120 * *$ & -25.040 \\
& $(32.464)$ & $(13.749)$ & $(15.498)$ \\
Observations & $1,246,808$ & $1,246,808$ & $1,246,808$ \\
Bandwidth & 527.1 & 719.7 & 628.1 \\
\hline \hline
\end{tabular}

Notes.-

Standard errors in parentheses. Eligibility for the Stimulus is defined strictly by Form W-2 wages. The running variable is W-2 wages. Reduced form are estimated using the optimal bandwidth selection approach by Calonico et al. (2016).

$* * * \mathrm{p}<0.01, * * \mathrm{p}<0.05, * \mathrm{p}<0.1$ 
Table A2: Validating Balance Tests

\begin{tabular}{cccc}
\hline \hline & Independent & Main Analysis & Placebo \\
& Variable & Full Sample & \\
\hline Panel A: Prob of Filing & & & \\
Reduced Form & Stimulus Eligible & $0.017^{* * *}$ & -0.0003 \\
Bandwidth & & $(0.004)$ & $(0.001)$ \\
IV & Filed in 2007 & $0.831^{* * *}$ & -0.06 .7 \\
& & $(0.187)$ & $(0.033)$ \\
Bandwidth & & 626.2 & 858.0 \\
Observations & & $8,727,656$ & $1,246,808$ \\
& & & \\
Panel B: Wage Earnings & & & \\
Reduced Form & Stimulus Eligible & $128^{* *}$ & -3 \\
Bandwidth & & $(50)$ & $(6)$ \\
IV & & 880.4 & 1122.2 \\
& Filed in 2007 & $5,663 * *$ & -237 \\
Bandwidth & & $(2,301)$ & $(350)$ \\
Observations & & 905.7 & 836.5 \\
Panel C: Prob of Claiming EITC & & $8,727,656$ & $1,246,808$ \\
Reduced Form & Stimulus Eligible & $0.006^{* * *}$ & -0.0005 \\
Bandwidth & & $(0.003)$ & $(0.0005)$ \\
IV & & 826.6 & 1173.5 \\
Bandwidth & Filed in 2007 & $0.265^{* * *}$ & -0.031 \\
Observations & & $(0.092)$ & $(0.027)$ \\
& & 993.6 & 868.6 \\
& & $9,974,464$ & $1,246,808$ \\
\hline
\end{tabular}

Notes.-

Standard errors in parentheses. Eligibility for the Stimulus is defined strictly by Form W-2 wages. The running variable is W-2 wages. For the placebo test, we regress the mean value of each outcome variable from 2008-2014 on all of the pre-treatment variables used in the balance tests listed in Table A1. We then use the predicted variable from that regression as the outcome variable in the reduced form Equation 1 and for the IV Equation 2, given respectively in Sections III.B and IV in the paper.

$* * * \mathrm{p}<0.01, * * \mathrm{p}<0.05,{ }^{*} \mathrm{p}<0.1$ 
Table A3: Regression Discontinuity, Probability of Filing a 2007 Tax Return

\begin{tabular}{l|cccccc}
\hline \hline & Female & Male & 25 to 34 & 35 to 44 & 45 and above & $\begin{array}{c}\text { Unrestricted } \\
\text { Sample }\end{array}$ \\
\hline Stimulus Eligible & $0.013^{*}$ & $0.028^{* * *}$ & $0.018^{* * *}$ & $0.019^{* *}$ & $0.028^{* * *}$ & $0.018^{* * *}$ \\
& $(0.007)$ & $(0.005)$ & $(0.006)$ & $(0.008)$ & $(0.008)$ & $(0.003)$ \\
Observations & 485,254 & 761,168 & 503,533 & 405,067 & 338,208 & $2,303,391$ \\
Bandwidth & 802.2 & 1010 & 1089 & 783.5 & 825.2 & 837.4 \\
\hline
\end{tabular}

Notes.-

The regression discontinuity (RD) estimates show the impact of stimulus eligibility on the probability of filing a 2007 tax return by gender and age. Standard errors are in parentheses. The RD is estimated using the optimal bandwidth selection approach by Calonico et al. (2016). Eligibility for the stimulus is defined strictly by Form $\mathrm{W}-2$ wages. The running variable is $\mathrm{W}-2$ wages.

$* * * \mathrm{p}<0.01, * * \mathrm{p}<0.05,{ }^{*} \mathrm{p}<0.1$ 
Table A4: Impact of Filing on Future Filing and EITC Claiming, by Year

\begin{tabular}{|c|c|c|c|c|c|c|c|c|c|}
\hline & $\begin{array}{c}\text { Independent } \\
\text { Variable }\end{array}$ & $\begin{array}{c}2007 \\
(1) \\
\end{array}$ & $\begin{array}{c}2008 \\
(2) \\
\end{array}$ & $\begin{array}{c}2009 \\
(3) \\
\end{array}$ & $\begin{array}{c}2010 \\
(4) \\
\end{array}$ & $\begin{array}{c}2011 \\
(5) \\
\end{array}$ & $\begin{array}{c}2012 \\
(6) \\
\end{array}$ & $\begin{array}{c}2013 \\
(7) \\
\end{array}$ & $\begin{array}{c}2014 \\
(8) \\
\end{array}$ \\
\hline \multicolumn{10}{|l|}{ Prob of Filing } \\
\hline Reduced Form & Stimulus Eligible & $\begin{array}{c}0.022 * * * \\
(0.004)\end{array}$ & $\begin{array}{c}0.018 * * * \\
(0.004)\end{array}$ & $\begin{array}{c}0.025 * * * \\
(0.005)\end{array}$ & $\begin{array}{c}0.011 * * * \\
(0.004)\end{array}$ & $\begin{array}{c}0.011 * * * \\
(0.004)\end{array}$ & $\begin{array}{c}0.014 * * * \\
(0.004)\end{array}$ & $\begin{array}{c}0.017 * * * \\
(0.004)\end{array}$ & $\begin{array}{c}0.017 * * * \\
(0.004)\end{array}$ \\
\hline Bandwidth & & 834.3 & 786.2 & 471.1 & 964.4 & 812.1 & 945.5 & 909.1 & 781.3 \\
\hline IV & Filed a 2007 Tax Return & & $0.700 * * *$ & $0.936^{* * *}$ & $0.653 * * *$ & $0.639 * * *$ & $0.961 * * *$ & $0.751 * * *$ & $0.800 * * *$ \\
\hline Bandwidth & & & $\begin{array}{l}(0.14 /) \\
1139\end{array}$ & $\begin{array}{l}(0.241) \\
584.2\end{array}$ & $\begin{array}{c}(0.20 /) \\
681.5\end{array}$ & $\begin{array}{c}(0.215) \\
643.0\end{array}$ & $\begin{array}{l}(0.2 / 0) \\
534.5\end{array}$ & $\begin{array}{l}(0.182) \\
1016\end{array}$ & $\begin{array}{c}(0.214) \\
740.5\end{array}$ \\
\hline \multicolumn{10}{|l|}{ Prob of Claiming EITC } \\
\hline Reduced Form & Stimulus Eligible & $\begin{array}{c}0.012 * * * \\
(0.004)\end{array}$ & $\begin{array}{l}0.007 * \\
(0.004)\end{array}$ & $\begin{array}{c}0.007 * * \\
(0.003)\end{array}$ & $\begin{array}{c}0.002 \\
(0.004)\end{array}$ & $\begin{array}{c}0.006 \\
(0.004)\end{array}$ & $\begin{array}{l}0.006^{*} \\
(0.004)\end{array}$ & $\begin{array}{c}0.005 \\
(0.003)\end{array}$ & $\begin{array}{c}0.007 * * \\
(0.003)\end{array}$ \\
\hline Bandwidth & & 1069 & 942.6 & 921.4 & 789.7 & 632.7 & 763.6 & 997.0 & 850.9 \\
\hline IV & Filed a 2007 Tax Return & $\begin{array}{c}0.488 * * * \\
(0.119)\end{array}$ & $\begin{array}{c}0.330 * * \\
(0.132)\end{array}$ & $\begin{array}{c}0.268 * * \\
(0.134)\end{array}$ & $\begin{array}{c}0.070 \\
(0.148)\end{array}$ & $\begin{array}{c}0.302 \\
(0.191)\end{array}$ & $\begin{array}{l}0.275^{*} \\
(0.145)\end{array}$ & $\begin{array}{l}0.231 * \\
(0.137)\end{array}$ & $\begin{array}{c}0.350 * * \\
(0.136)\end{array}$ \\
\hline Bandwidth & & 921.2 & 1260 & 1186 & 972.0 & 560.7 & 939.8 & 1062 & 1076 \\
\hline Observations & & $1,246,808$ & $1,246,808$ & $1,246,808$ & $1,246,808$ & $1,246,808$ & $1,246,808$ & $1,246,808$ & $1,246,808$ \\
\hline
\end{tabular}

Notes.-

The reduced form estimates show the impact of stimulus eligibility on the outcome variable. The IV estimates, where stimulus eligibility is used to instrument for filing a 2007 tax return, are reported only for the second stage. The first stage regression results (not shown) estimates the impact of stimulus eligibility on filing a 2007 tax return. Standard errors are in parentheses. Reduced form and IV are estimated using the optimal bandwidth selection approach by Calonico et al. (2016). Eligibility for the stimulus is defined strictly by Form W-2 wages. The running variable is W-2 wages.

$* * * \mathrm{p}<0.01, * * \mathrm{p}<0.05, * \mathrm{p}<0.1$ 
Table A5: Impact of Filing on Wage Earnings, by Year

\begin{tabular}{|c|c|c|c|c|c|c|c|c|}
\hline & $\begin{array}{c}\text { Independent } \\
\text { Variable }\end{array}$ & $\begin{array}{c}2008 \\
(1) \\
\end{array}$ & $\begin{array}{c}2009 \\
(2) \\
\end{array}$ & $\begin{array}{c}2010 \\
(3) \\
\end{array}$ & $\begin{array}{c}2011 \\
(4) \\
\end{array}$ & $\begin{array}{c}2012 \\
(5) \\
\end{array}$ & $\begin{array}{c}2013 \\
(6) \\
\end{array}$ & $\begin{array}{c}2014 \\
(7) \\
\end{array}$ \\
\hline \multicolumn{9}{|l|}{ Wage Earnings } \\
\hline Reduced Form & Stimulus Eligible & $\begin{array}{l}89.209 * \\
(48.098)\end{array}$ & $\begin{array}{c}113.933 * * \\
(54.832)\end{array}$ & $\begin{array}{c}104.976^{*} \\
(54.718)\end{array}$ & $\begin{array}{c}146.542 * * \\
(65.963)\end{array}$ & $\begin{array}{c}124.054 * * \\
(62.068)\end{array}$ & $\begin{array}{c}144.206^{* * *} \\
(67.997)\end{array}$ & $\begin{array}{c}148.221 * * \\
(69.687)\end{array}$ \\
\hline Bandwidth & & 977.7 & 888.5 & 995.2 & 761.6 & 963.2 & 887.4 & 927.2 \\
\hline IV & Filed a 2007 Tax Return & $4,033.118^{*}$ & $3,993.459 *$ & $4,241.123^{*}$ & $7,094.500 * *$ & $8,449.021 * *$ & $5,348.704 * *$ & $6,213.350 * *$ \\
\hline Bandwidth & & 996.8 & 1089 & 1263 & $\begin{array}{l}(J, 2 J 0.402) \\
692.0\end{array}$ & $\begin{array}{c}(3,340.503) \\
685.4\end{array}$ & $\begin{array}{l}(2, / 09.521) \\
1232\end{array}$ & $\begin{array}{c}(2,908.8 / 4) \\
1111\end{array}$ \\
\hline Observations & & $1,246,808$ & $1,246,808$ & $1,246,808$ & $1,246,808$ & $1,246,808$ & $1,246,808$ & $1,246,808$ \\
\hline
\end{tabular}

Notes.-

6 The reduced form estimates show the impact of stimulus eligibility on the outcome variable. The IV estimates, where stimulus eligibility is used to instrument for filing a 2007 tax return, are reported only for the second stage. The first stage regression results (not shown) estimates the impact of stimulus eligibility on filing a 2007 tax return. Standard errors are in parentheses. Reduced form and IV are estimated using the optimal bandwidth selection approach by Calonico et al. (2016). Eligibility for the stimulus is defined strictly by Form W-2 wages. The running variable is W-2 wages. The outcome wages is top coded to the 95 th percentile in each year.

$* * * \mathrm{p}<0.01, * * \mathrm{p}<0.05, * \mathrm{p}<0.1$ 
Table A6: Impact of Filing on Poverty, by Year

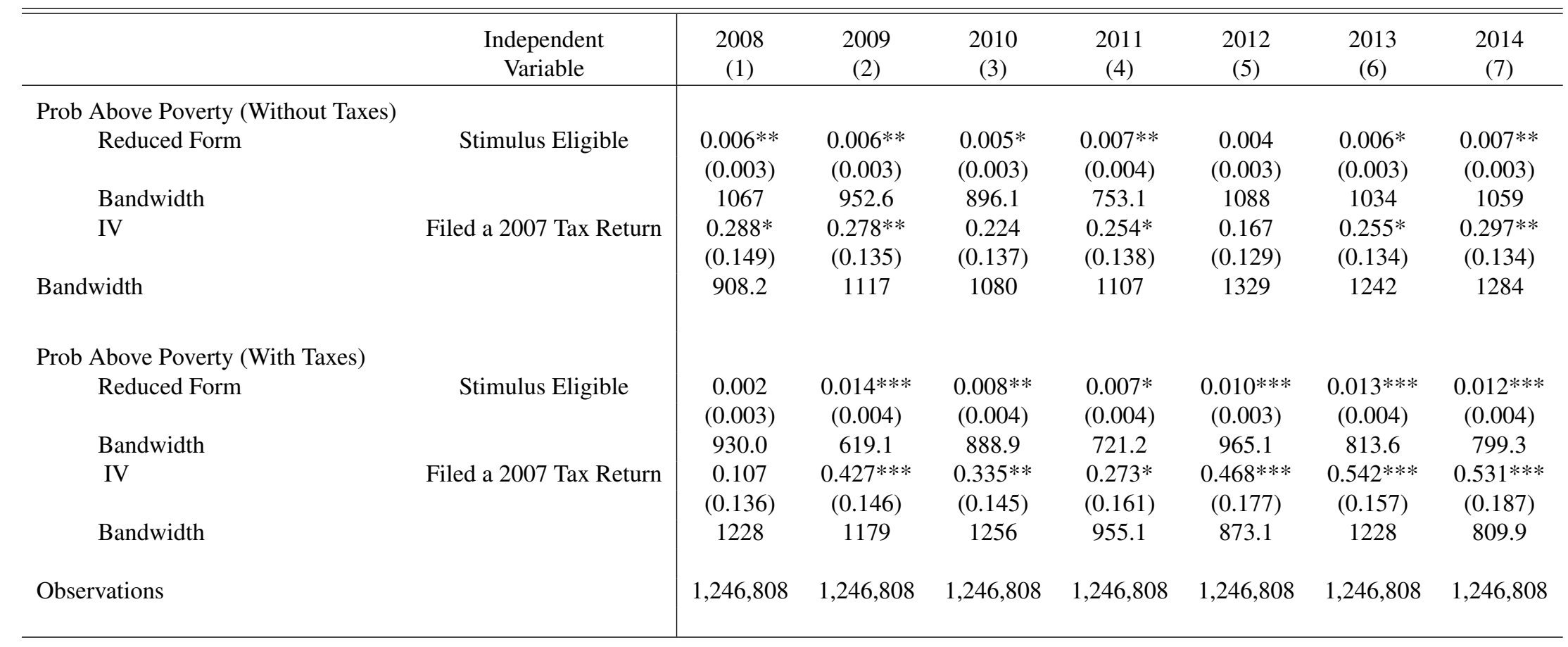

Notes.-

The reduced form estimates show the impact of stimulus eligibility on the outcome variable. The IV estimates, where stimulus eligibility is used to instrument for filing a 2007 tax return, are reported only for the second stage. The first stage regression results (not shown) estimates the impact of stimulus eligibility on filing a 2007 tax return. Standard errors are in parentheses. Reduced form and IV are estimated using the optimal bandwidth selection approach by Calonico et al. (2016). Eligibility for the stimulus is defined strictly by Form W-2 wages. The running variable is W-2 wages. The tax exclusive income used to determine poverty status is constructed from information return forms that are issued to both filers and non-filers including wage income from the Form W-2, and dividends, capital gains, unemployment benefits, interest income, non-employee compensation, and social security income from Forms 1099s. The tax inclusive income measure to determine poverty for non-filers is measured as the income from information returns minus payroll taxes and withholdings, and for filers, is measured as the tax return income minus payroll taxes and the tax return's balance. For the tax exclusive measure of poverty, we assume that each individual is unmarried and that he/she lives in a household with his/her biological children. An individual's biological child is defined as any person under age 19 who lists the individual as a parent. We identify biological children using administrative data from the Social Security Administration. For the tax-inclusive measure of poverty, each non-filer's size is defined in the same way as in the tax-exclusive income measure where we assume that each individual is unmarried and claims their biological children. For filers, household size is defined by the number of exemptions claimed on the tax return.

$* * * \mathrm{p}<0.01, * * \mathrm{p}<0.05, * \mathrm{p}<0.1$ 
Table A7: Probability of Filing a 2007 Tax Return; Higher-Order Polynomials

\begin{tabular}{l|ccc}
\hline \hline & 1st order & 2nd Order & 3rd Order \\
\hline Stimulus Eligible & $0.021 * * *$ & $0.024 * * *$ & $0.022^{* * *}$ \\
& $(0.004)$ & $(0.005)$ & $(0.006)$ \\
Observations & $1,246,808$ & $1,246,808$ & $1,246,808$ \\
Bandwidth & 834.3 & 1499 & 1486 \\
\hline
\end{tabular}

Notes.-

The regression discontinuity (RD) estimates show the impact of stimulus eligibility on the outcome variable. Standard errors are in parentheses. The RD is estimated using the optimal bandwidth selection approach by Calonico et al. (2016). Eligibility for the stimulus is defined strictly by Form W-2 wages. The running variable is $\mathrm{W}-2$ wages.

$* * * \mathrm{p}<0.01, * * \mathrm{p}<0.05, * \mathrm{p}<0.1$ 
Table A8: Wage Earnings Results Using Higher Order Polynomial

\begin{tabular}{|c|c|c|c|c|c|c|c|c|}
\hline & $\begin{array}{c}\text { Independent } \\
\text { Variable }\end{array}$ & $\begin{array}{c}2008 \\
(1) \\
\end{array}$ & $\begin{array}{c}2009 \\
(2) \\
\end{array}$ & $\begin{array}{c}2010 \\
(3) \\
\end{array}$ & $\begin{array}{c}2011 \\
(4) \\
\end{array}$ & $\begin{array}{c}2012 \\
(5) \\
\end{array}$ & $\begin{array}{c}2013 \\
(6) \\
\end{array}$ & $\begin{array}{c}2014 \\
(7) \\
\end{array}$ \\
\hline \multicolumn{9}{|l|}{ 2nd Order } \\
\hline Reduced Form & Stimulus Eligible & $\begin{array}{l}103.802 \\
(65.057)\end{array}$ & $\begin{array}{c}170.063 * * \\
(71.890)\end{array}$ & $\begin{array}{c}138.860 * * \\
(63.248)\end{array}$ & $\begin{array}{c}177.863 * * \\
(76.635)\end{array}$ & $\begin{array}{c}271.287 * * * \\
\quad(94.359)\end{array}$ & $\begin{array}{c}247.735 * * \\
(96.367)\end{array}$ & $\begin{array}{c}282.565 * * * \\
(104.586)\end{array}$ \\
\hline Bandwidth & & 1135 & 1099 & 1585 & 1203 & 891.0 & 941.6 & 878.6 \\
\hline IV & Filed a 2007 Tax Return & $\begin{array}{c}4,753.562 \\
(2,943.439)\end{array}$ & $\begin{array}{c}6,456.148 * * \\
(3,031.510)\end{array}$ & $\begin{array}{c}6,178.569 * * \\
(3,095.539)\end{array}$ & $\begin{array}{c}7,768.768 * * \\
(3,535.981)\end{array}$ & $\begin{array}{c}8,768.642 * * \\
(3,723.777)\end{array}$ & $\begin{array}{c}7,118.380 * * \\
(3,258.326)\end{array}$ & $\begin{array}{c}8,419.458 * * \\
(3,922.855)\end{array}$ \\
\hline Bandwidth & & 1054 & 1248 & 1304 & 1215 & 1260 & 1501 & 1300 \\
\hline \multicolumn{9}{|l|}{ 3rd Order } \\
\hline Reduced Form & Stimulus Eligible & $\begin{array}{c}84.363 \\
(70.107)\end{array}$ & $\begin{array}{c}211.728 * * \\
(91.887)\end{array}$ & $\begin{array}{c}191.272 * * \\
(92.269)\end{array}$ & $\begin{array}{c}231.468 * * \\
(101.519)\end{array}$ & $\begin{array}{c}329.235^{* * *} \\
(110.364)\end{array}$ & $\begin{array}{c}318.781 * * * \\
(114.658)\end{array}$ & $\begin{array}{c}339.240 * * * \\
(122.153)\end{array}$ \\
\hline Bandwidth & & 1679 & 1154 & 1276 & 1173 & 1114 & 1138 & 1100 \\
\hline IV & Filed a 2007 Tax Return & $\begin{array}{c}4,921.735 \\
(3,499.343)\end{array}$ & $\begin{array}{c}9,423.818 * * \\
(4,258.443)\end{array}$ & $\begin{array}{c}7,212.365^{*} \\
(3,815.258)\end{array}$ & $\begin{array}{c}8,655.354 * * \\
(3,859.163)\end{array}$ & $\begin{array}{c}12,585.193 * * \\
(5,262.494)\end{array}$ & $\begin{array}{c}12,807.840 * * \\
(5,652.719)\end{array}$ & $\begin{array}{c}13,405.152 * * \\
(5,900.891)\end{array}$ \\
\hline Bandwidth & & 1364 & 1299 & 1643 & 1762 & 1463 & 1267 & 1284 \\
\hline Observations & & $1,246,808$ & $1,246,808$ & $1,246,808$ & $1,246,808$ & $1,246,808$ & $1,246,808$ & $1,246,808$ \\
\hline
\end{tabular}

Notes.-

The reduced form estimates show the impact of stimulus eligibility on the outcome variable. The IV estimates, where stimulus eligibility is used to instrument for filing a 2007 tax return, are reported only for the second stage. The first stage regression results (not shown) estimates the impact of stimulus eligibility on filing a 2007 tax return. Standard errors are in parentheses. Reduced form and IV are estimated using the optimal bandwidth selection approach by Calonico et al. (2016). Eligibility for the stimulus is defined strictly by Form W-2 wages. The running variable is W-2 wages.

$* * * \mathrm{p}<0.01, * * \mathrm{p}<0.05, * \mathrm{p}<0.1$ 
Table A9: Poverty Results Using 2nd Order Polynomial

\begin{tabular}{|c|c|c|c|c|c|c|c|c|}
\hline & $\begin{array}{l}\text { Independent } \\
\text { Variable }\end{array}$ & $\begin{array}{c}2008 \\
(1)\end{array}$ & $\begin{array}{c}2009 \\
(2)\end{array}$ & $\begin{array}{c}2010 \\
(3)\end{array}$ & $\begin{array}{c}2011 \\
(4)\end{array}$ & $\begin{array}{c}2012 \\
(5)\end{array}$ & $\begin{array}{c}2013 \\
(6)\end{array}$ & $\begin{array}{c}2014 \\
(7)\end{array}$ \\
\hline \multicolumn{9}{|c|}{ Prob Above Poverty (Without Taxes) } \\
\hline Reduced Form & Stimulus Eligible & $\begin{array}{c}0.006 \\
(0.004)\end{array}$ & $\begin{array}{c}0.008 * * \\
(0.004)\end{array}$ & $\begin{array}{l}0.007 * \\
(0.004)\end{array}$ & $\begin{array}{c}0.008 * * \\
(0.004)\end{array}$ & $\begin{array}{l}0.008 * \\
(0.004)\end{array}$ & $\begin{array}{c}0.010 * * \\
(0.005)\end{array}$ & $\begin{array}{c}0.013 * * * \\
(0.005)\end{array}$ \\
\hline Bandwidth & \multirow{4}{*}{ Filed a 2007 Tax Return } & 1032 & 1481 & 1348 & 1307 & 1077 & 974.6 & 887.8 \\
\hline \multirow[t]{2}{*}{ IV } & & 0.259 & $0.367 *$ & $0.307 *$ & $0.378 *$ & 0.258 & $0.344 * *$ & $0.430 * *$ \\
\hline & & $(0.194)$ & $(0.189)$ & $(0.172)$ & $(0.196)$ & $(0.172)$ & $(0.171)$ & $(0.189)$ \\
\hline Bandwidth & & 1058 & 1177 & 1335 & 1160 & 1336 & 1393 & 1301 \\
\hline \multicolumn{9}{|c|}{ Prob Above Poverty (With Taxes) } \\
\hline Reduced Form & Stimulus Eligible & $\begin{array}{c}0.002 \\
(0.005)\end{array}$ & $\begin{array}{c}0.016 * * * \\
(0.005)\end{array}$ & $\begin{array}{c}0.010 * * \\
(0.004)\end{array}$ & $\begin{array}{l}0.008 * \\
(0.005)\end{array}$ & $\begin{array}{c}0.012 * * * \\
(0.004)\end{array}$ & $\begin{array}{c}0.015^{* * *} * \\
(0.004)\end{array}$ & $\begin{array}{c}0.023 * * * \\
(0.006)\end{array}$ \\
\hline Bandwidth & \multirow{4}{*}{ Filed a 2007 Tax Return } & 1088 & 1021 & 1307 & 1212 & 1391 & 1580 & 750.6 \\
\hline IV & & 0.113 & $0.613 * * *$ & $0.422 * *$ & $0.374 *$ & $0.577 * *$ & $0.650 * * *$ & $0.604 * * *$ \\
\hline & & $(0.208)$ & $(0.210)$ & $(0.202)$ & $(0.212)$ & $(0.238)$ & $(0.229)$ & $(0.213)$ \\
\hline Bandwidth & & 1009 & 1269 & 1272 & 1169 & 1062 & 1216 & 1300 \\
\hline Observations & & $1,246,808$ & $1,246,808$ & $1,246,808$ & $1,246,808$ & $1,246,808$ & $1,246,808$ & $1,246,808$ \\
\hline
\end{tabular}

Notes.-

The reduced form estimates show the impact of stimulus eligibility on the outcome variable. The IV estimates, where stimulus eligibility is used to instrument for filing a 2007 tax return, are reported only for the second stage. The first stage regression results (not shown) estimates the impact of stimulus eligibility on filing a 2007 tax return. Standard errors are in parentheses. Reduced form and IV are estimated using the optimal bandwidth selection approach by Calonico et al. (2016). Eligibility for the stimulus is defined strictly by Form W-2 wages. The running variable is W-2 wages. The tax exclusive income used to determine poverty status is constructed from information return forms that are issued to both filers and non-filers including wage income from the Form W-2, and dividends, capital gains, unemployment benefits, interest income, non-employee compensation, and social security income from Forms 1099s. The tax inclusive income measure to determine poverty for non-filers is measured as the income from information returns minus payroll taxes and withholdings, and for filers, is measured as the tax return income minus payroll taxes and the tax return's balance. For the tax exclusive measure of poverty, we assume that each individual is unmarried and that he/she lives in a household with his/her biological children. An individual's biological child is defined as any person under age 19 who lists the individual as a parent. We identify biological children using administrative data from the Social Security Administration. For the tax-inclusive measure of poverty, each non-filer's size is defined in the same way as in the tax-exclusive income measure where we assume that each individual is unmarried and claims their biological children. For filers, household size is defined by the number of exemptions claimed on the tax return.

$* * * \mathrm{p}<0.01, * * \mathrm{p}<0.05, * \mathrm{p}<0.1$ 
Table A10: Poverty Results Using 3rd Order Polynomial

\begin{tabular}{|c|c|c|c|c|c|c|c|c|}
\hline & $\begin{array}{c}\text { Independent } \\
\text { Variable }\end{array}$ & $\begin{array}{c}2008 \\
(1)\end{array}$ & $\begin{array}{c}2009 \\
(2)\end{array}$ & $\begin{array}{c}2010 \\
(3)\end{array}$ & $\begin{array}{c}2011 \\
(4)\end{array}$ & $\begin{array}{c}2012 \\
(5)\end{array}$ & $\begin{array}{c}2013 \\
(6)\end{array}$ & $\begin{array}{c}2014 \\
(7)\end{array}$ \\
\hline \multicolumn{9}{|c|}{ Prob Above Poverty (Without Taxes) } \\
\hline Reduced Form & Stimulus Eligible & $\begin{array}{c}0.006 \\
(0.005)\end{array}$ & $\begin{array}{l}0.011 * \\
(0.005)\end{array}$ & $\begin{array}{l}0.010 * \\
(0.005)\end{array}$ & $\begin{array}{c}0.011 * * \\
(0.006)\end{array}$ & $\begin{array}{c}0.014 * * \\
(0.006)\end{array}$ & $\begin{array}{c}0.013 * * \\
(0.006)\end{array}$ & $\begin{array}{c}0.016 * * * \\
(0.006)\end{array}$ \\
\hline Bandwidth & \multirow{4}{*}{ Filed a 2007 Tax Return } & 1334 & 1154 & 1170 & 1179 & 1029 & 1176 & 1088 \\
\hline & & 0.246 & $0.464 *$ & $0.404 *$ & $0.431 *$ & $0.501 *$ & $0.532 * *$ & $0.631 * *$ \\
\hline & & $(0.228)$ & $(0.247)$ & $(0.237)$ & $(0.237)$ & $(0.260)$ & $(0.265)$ & $(0.280)$ \\
\hline Bandwidth & & 1401 & 1343 & 1468 & 1534 & 1272 & 1304 & 1331 \\
\hline \multicolumn{9}{|c|}{ Prob Above Poverty (With Taxes) } \\
\hline Reduced Form & Stimulus Eligible & $\begin{array}{c}0.003 \\
(0.006)\end{array}$ & $\begin{array}{c}0.017 * * * \\
(0.006)\end{array}$ & $\begin{array}{c}0.015 * * \\
(0.006)\end{array}$ & $\begin{array}{l}0.010 * \\
(0.006)\end{array}$ & $\begin{array}{c}0.017 * * * \\
(0.006)\end{array}$ & $\begin{array}{c}0.017 * * * \\
(0.006)\end{array}$ & $\begin{array}{c}0.028 * * * \\
(0.007)\end{array}$ \\
\hline Bandwidth & \multirow{3}{*}{ Filed a 2007 Tax Return } & 1238 & 1106 & 1100 & 1201 & 1104 & 1243 & 946.1 \\
\hline IV & & 0.034 & $0.638 * * *$ & $0.587 * *$ & 0.433 & $0.570 * *$ & $0.735^{* *}$ & $1.058 * * *$ \\
\hline & & $(0.212)$ & $(0.229)$ & $(0.283)$ & $(0.267)$ & $(0.257)$ & $(0.306)$ & $(0.376)$ \\
\hline Bandwidth & & 1694 & 1800 & 1352 & 1411 & 1623 & 1353 & 1165 \\
\hline Observations & & $1,246,808$ & $1,246,808$ & $1,246,808$ & $1,246,808$ & $1,246,808$ & $1,246,808$ & $1,246,808$ \\
\hline
\end{tabular}

Notes.-

The reduced form estimates show the impact of stimulus eligibility on the outcome variable. The IV estimates, where stimulus eligibility is used to instrument for filing a 2007 tax return, are reported only for the second stage. The first stage regression results (not shown) estimates the impact of stimulus eligibility on filing a 2007 tax return. Standard errors are in parentheses. Reduced form and IV are estimated using the optimal bandwidth selection approach by Calonico et al. (2016). Eligibility for the stimulus is defined strictly by Form W-2 wages. The running variable is W-2 wages. The tax exclusive income used to determine poverty status is constructed from information return forms that are issued to both filers and non-filers including wage income from the Form W-2, and dividends, capital gains, unemployment benefits, interest income, non-employee compensation, and social security income from Forms 1099s. The tax inclusive income measure to determine poverty for non-filers is measured as the income from information returns minus payroll taxes and withholdings, and for filers, is measured as the tax return income minus payroll taxes and the tax return's balance. For the tax exclusive measure of poverty, we assume that each individual is unmarried and that he/she lives in a household with his/her biological children. An individual's biological child is defined as any person under age 19 who lists the individual as a parent. We identify biological children using administrative data from the Social Security Administration. For the tax-inclusive measure of poverty, each non-filer's size is defined in the same way as in the tax-exclusive income measure where we assume that each individual is unmarried and claims their biological children. For filers, household size is defined by the number of exemptions claimed on the tax return.

$* * * \mathrm{p}<0.01, * * \mathrm{p}<0.05, * \mathrm{p}<0.1$ 
Table A11: Probability of Filing a 2007 Tax Return; Varying Bandwidth Choice

\begin{tabular}{l|ccc}
\hline \hline Bandwidth & 500 & 1000 & 1500 \\
\hline Stimulus Eligible & $\begin{array}{c}0.022 * * * \\
(0.005)\end{array}$ & $\begin{array}{c}0.022 * * * \\
(0.004)\end{array}$ & $\begin{array}{c}0.020 * * * \\
(0.003)\end{array}$ \\
& & & \\
Observations & $1,246,808$ & $1,246,808$ & $1,246,808$ \\
\hline \hline
\end{tabular}

Notes.-

Standard errors are in parentheses. The RD is estimated using the optimal bandwidth selection approach by Calonico et al. (2016). Eligibility for the Stimulus is defined strictly by Form W-2 wages. The running variable is $\mathrm{W}-2$ wages.

$* * * \mathrm{p}<0.01, * * \mathrm{p}<0.05, * \mathrm{p}<0.1$ 
Table A12: Wage Earnings and Poverty Results Using 500 Bandwidth

\begin{tabular}{|c|c|c|c|c|c|c|c|c|}
\hline & $\begin{array}{c}\text { Independent } \\
\text { Variable }\end{array}$ & $\begin{array}{c}2008 \\
(1) \\
\end{array}$ & $\begin{array}{c}2009 \\
(2) \\
\end{array}$ & $\begin{array}{c}2010 \\
(3) \\
\end{array}$ & $\begin{array}{c}2011 \\
(4) \\
\end{array}$ & $\begin{array}{c}2012 \\
(5) \\
\end{array}$ & $\begin{array}{c}2013 \\
(6) \\
\end{array}$ & $\begin{array}{c}2014 \\
(7) \\
\end{array}$ \\
\hline \multicolumn{9}{|l|}{ Wage Earnings } \\
\hline Reduced Form & Stimulus Eligible & $\begin{array}{c}90.312 \\
(67.234)\end{array}$ & $\begin{array}{c}161.374 * * \\
(73.198)\end{array}$ & $\begin{array}{c}154.763 * * \\
(77.329)\end{array}$ & $\begin{array}{c}178.599 * * \\
(81.573)\end{array}$ & $\begin{array}{c}247.058 * * * \\
\quad(86.455)\end{array}$ & $\begin{array}{c}245.003 * * * \\
(90.793)\end{array}$ & $\begin{array}{c}254.074 * * * \\
\quad(95.169)\end{array}$ \\
\hline IV & Filed a 2007 Tax Return & $\begin{array}{c}4,043.942 \\
(2,936.536)\end{array}$ & $\begin{array}{l}7,225.917 * * \\
(3,396.660)\end{array}$ & $\begin{array}{l}6,929.904 * \\
(3,573.855)\end{array}$ & $\begin{array}{l}7,997.215^{* *} \\
(3,851.199)\end{array}$ & $\begin{array}{c}11,062.653 * * \\
(4,376.040)\end{array}$ & $\begin{array}{c}10,970.631 * * \\
(4,542.064)\end{array}$ & $\begin{array}{c}11,376.804 * * \\
(4,741.081)\end{array}$ \\
\hline \multicolumn{9}{|c|}{ Prob Above Poverty (Without Taxes) } \\
\hline Reduced Form & Stimulus Eligible & $\begin{array}{c}0.005 \\
(0.004)\end{array}$ & $\begin{array}{c}0.009 * * \\
(0.004)\end{array}$ & $\begin{array}{l}0.008 * \\
(0.004)\end{array}$ & $\begin{array}{l}0.009 * \\
(0.004)\end{array}$ & $\begin{array}{c}0.009 * * \\
(0.004)\end{array}$ & $\begin{array}{c}0.010 * * \\
(0.004)\end{array}$ & $\begin{array}{c}0.012 * * * \\
(0.004)\end{array}$ \\
\hline IV & Filed a 2007 Tax Return & $\begin{array}{c}0.229 \\
(0.194)\end{array}$ & $\begin{array}{c}0.406 * * \\
(0.204)\end{array}$ & $\begin{array}{l}0.370 * \\
(0.204)\end{array}$ & $\begin{array}{l}0.387^{*} \\
(0.208)\end{array}$ & $\begin{array}{l}0.392 * \\
(0.209)\end{array}$ & $\begin{array}{c}0.468 * * \\
(0.218)\end{array}$ & $\begin{array}{c}0.535 * * \\
(0.225)\end{array}$ \\
\hline \multicolumn{9}{|c|}{ Prob Above Poverty (With Taxes) } \\
\hline Reduced Form & Stimulus Eligible & $\begin{array}{c}0.002 \\
(0.005)\end{array}$ & $\begin{array}{c}0.015 * * * \\
(0.005)\end{array}$ & $\begin{array}{c}0.012 * * \\
(0.005)\end{array}$ & $\begin{array}{l}0.008 * \\
(0.005)\end{array}$ & $\begin{array}{c}0.013^{* * * *} \\
(0.005)\end{array}$ & $\begin{array}{c}0.015 * * * \\
(0.005)\end{array}$ & $\begin{array}{c}0.018 * * * \\
(0.005)\end{array}$ \\
\hline IV & Filed a 2007 Tax Return & $\begin{array}{c}0.095 \\
(0.205)\end{array}$ & $\begin{array}{c}0.668 * * * \\
(0.241)\end{array}$ & $\begin{array}{c}0.526 * * \\
(0.233)\end{array}$ & $\begin{array}{l}0.376^{*} \\
(0.224)\end{array}$ & $\begin{array}{c}0.604 * * \\
(0.243)\end{array}$ & $\begin{array}{c}0.681 * * * \\
(0.252)\end{array}$ & $\begin{array}{c}0.799 * * * \\
(0.268)\end{array}$ \\
\hline Observations & & $1,246,808$ & $1,246,808$ & $1,246,808$ & $1,246,808$ & $1,246,808$ & $1,246,808$ & $1,246,808$ \\
\hline
\end{tabular}

Notes.-

The reduced form estimates show the impact of stimulus eligibility on the outcome variable. The IV estimates, where stimulus eligibility is used to instrument for filing a 2007 tax return, are reported only for the second stage. The first stage regression results (not shown) estimates the impact of stimulus eligibility on filing a 2007 tax return. Standard errors are in parentheses. Reduced form and IV are estimated using a \$500 bandwidth. Eligibility for the stimulus is defined strictly by Form W-2 wages. The running variable is W-2 wages. The outcome wages is top coded to the 95th percentile in each year.

$* * * \mathrm{p}<0.01, * * \mathrm{p}<0.05, * \mathrm{p}<0.1$ 
Table A13: Wage Earnings and Poverty Results Using 1000 Bandwidth

\begin{tabular}{|c|c|c|c|c|c|c|c|c|}
\hline & $\begin{array}{c}\text { Independent } \\
\text { Variable }\end{array}$ & $\begin{array}{c}2008 \\
(1) \\
\end{array}$ & $\begin{array}{c}2009 \\
(2) \\
\end{array}$ & $\begin{array}{c}2010 \\
(3) \\
\end{array}$ & $\begin{array}{c}2011 \\
(4) \\
\end{array}$ & $\begin{array}{c}2012 \\
(5) \\
\end{array}$ & $\begin{array}{c}2013 \\
(6) \\
\end{array}$ & $\begin{array}{c}2014 \\
(7) \\
\end{array}$ \\
\hline \multicolumn{9}{|l|}{ Wage Earnings } \\
\hline Reduced Form & Stimulus Eligible & $\begin{array}{l}88.208 * \\
(47.561)\end{array}$ & $\begin{array}{l}94.758 * \\
(51.659)\end{array}$ & $\begin{array}{c}104.596 * \\
(54.586)\end{array}$ & $\begin{array}{c}102.709 * \\
(57.471)\end{array}$ & $\begin{array}{c}116.958 * \\
(60.905)\end{array}$ & $\begin{array}{c}128.436 * * \\
(63.993)\end{array}$ & $\begin{array}{c}138.298 * * \\
(67.068)\end{array}$ \\
\hline IV & Filed a 2007 Tax Return & $\begin{array}{l}4,030.122 * \\
(2,123.809)\end{array}$ & $\begin{array}{l}4,329.404^{*} \\
(2,336.600)\end{array}$ & $\begin{array}{l}4,778.847^{*} \\
(2,490.689)\end{array}$ & $\begin{array}{l}4,692.646^{*} \\
(2,624.120)\end{array}$ & $\begin{array}{l}5,343.681^{*} \\
(2,804.224)\end{array}$ & $\begin{array}{c}5,868.083 * * \\
(2,963.923)\end{array}$ & $\begin{array}{c}6,318.694 * * \\
(3,107.434)\end{array}$ \\
\hline Observations & & $1,246,808$ & $1,246,808$ & $1,246,808$ & $1,246,808$ & $1,246,808$ & $1,246,808$ & $1,246,808$ \\
\hline \multicolumn{9}{|c|}{ Prob Above Poverty (Without Taxes) } \\
\hline Reduced Form & Stimulus Eligible & $\begin{array}{c}0.006 * * \\
(0.003)\end{array}$ & $\begin{array}{c}0.006 * * \\
(0.003)\end{array}$ & $\begin{array}{c}0.005 \\
(0.003)\end{array}$ & $\begin{array}{l}0.006 * \\
(0.003)\end{array}$ & $\begin{array}{c}0.004 \\
(0.003)\end{array}$ & $\begin{array}{l}0.006 * \\
(0.003)\end{array}$ & $\begin{array}{c}0.007 * * \\
(0.003)\end{array}$ \\
\hline IV & Filed a 2007 Tax Return & $\begin{array}{c}0.285 * * \\
(0.142)\end{array}$ & $\begin{array}{c}0.282 * * \\
(0.141)\end{array}$ & $\begin{array}{c}0.229 \\
(0.142)\end{array}$ & $\begin{array}{l}0.268^{*} \\
(0.144)\end{array}$ & $\begin{array}{c}0.184 \\
(0.143)\end{array}$ & $\begin{array}{l}0.278^{*} \\
(0.146)\end{array}$ & $\begin{array}{c}0.327 * * \\
(0.149)\end{array}$ \\
\hline Observations & & $1,246,808$ & $1,246,808$ & $1,246,808$ & $1,246,808$ & $1,246,808$ & $1,246,808$ & $1,246,808$ \\
\hline \multicolumn{9}{|c|}{ Prob Above Poverty (With Taxes) } \\
\hline Reduced Form & Stimulus Eligible & $\begin{array}{c}0.002 \\
(0.003)\end{array}$ & $\begin{array}{c}0.010 * * * \\
(0.003)\end{array}$ & $\begin{array}{c}0.008 * * \\
(0.003)\end{array}$ & $\begin{array}{c}0.006 \\
(0.003)\end{array}$ & $\begin{array}{c}0.010 * * * \\
(0.003)\end{array}$ & $\begin{array}{c}0.012 * * * \\
(0.003)\end{array}$ & $\begin{array}{c}0.010 * * * \\
(0.003)\end{array}$ \\
\hline IV & Filed a 2007 Tax Return & $\begin{array}{c}0.087 \\
(0.148)\end{array}$ & $\begin{array}{c}0.472 * * * \\
(0.159)\end{array}$ & $\begin{array}{c}0.349 * * \\
(0.159)\end{array}$ & $\begin{array}{c}0.259 \\
(0.158)\end{array}$ & $\begin{array}{c}0.436 * * * \\
(0.164)\end{array}$ & $\begin{array}{c}0.564 * * * \\
(0.172)\end{array}$ & $\begin{array}{c}0.444 * * * \\
(0.163)\end{array}$ \\
\hline Observations & & $1,246,808$ & $1,246,808$ & $1,246,808$ & $1,246,808$ & $1,246,808$ & $1,246,808$ & $1,246,808$ \\
\hline
\end{tabular}

Notes.-

The reduced form estimates show the impact of stimulus eligibility on the outcome variable. The IV estimates, where stimulus eligibility is used to instrument for filing a 2007 tax return, are reported only for the second stage. The first stage regression results (not shown) estimates the impact of stimulus eligibility on filing a 2007 tax return. Standard errors are in parentheses. Reduced form and IV are estimated using a \$1000 bandwidth. Eligibility for the stimulus is defined strictly by Form W-2 wages. The running variable is W-2 wages. The outcome wages is top coded to the 95 th percentile in each year. $* * * \mathrm{p}<0.01, * * \mathrm{p}<0.05, * \mathrm{p}<0.1$ 
Table A14: Wage Earnings and Poverty Results Using 1500 Bandwidth

\begin{tabular}{|c|c|c|c|c|c|c|c|c|}
\hline & $\begin{array}{c}\text { Independent } \\
\text { Variable }\end{array}$ & $\begin{array}{c}2008 \\
(1) \\
\end{array}$ & $\begin{array}{c}2009 \\
(2) \\
\end{array}$ & $\begin{array}{c}2010 \\
(3) \\
\end{array}$ & $\begin{array}{c}2011 \\
(4) \\
\end{array}$ & $\begin{array}{c}2012 \\
(5) \\
\end{array}$ & $\begin{array}{c}2013 \\
(6) \\
\end{array}$ & $\begin{array}{c}2014 \\
(7) \\
\end{array}$ \\
\hline \multicolumn{9}{|l|}{ Wage Earnings } \\
\hline Reduced Form & Stimulus Eligible & $\begin{array}{l}81.340 * * \\
(38.775)\end{array}$ & $\begin{array}{c}66.844 \\
(42.072)\end{array}$ & $\begin{array}{l}73.383 * \\
(44.440)\end{array}$ & $\begin{array}{c}44.723 \\
(46.745)\end{array}$ & $\begin{array}{c}61.882 \\
(49.542)\end{array}$ & $\begin{array}{l}95.655^{*} \\
(52.067)\end{array}$ & $\begin{array}{c}110.028 * * \\
(54.564)\end{array}$ \\
\hline IV & Filed a 2007 Tax Return & $\begin{array}{c}4,168.825 * * \\
(1,945.229)\end{array}$ & $\begin{array}{c}3,425.897 \\
(2,121.094)\end{array}$ & $\begin{array}{l}3,761.032 * \\
(2,253.458)\end{array}$ & $\begin{array}{c}2,292.134 \\
(2,365.140)\end{array}$ & $\begin{array}{c}3,171.556 \\
(2,515.562)\end{array}$ & $\begin{array}{l}4,902.539^{*} \\
(2,676.374)\end{array}$ & $\begin{array}{r}5,639.148 * * \\
(2,813.635)\end{array}$ \\
\hline Observations & & $1,246,808$ & $1,246,808$ & $1,246,808$ & $1,246,808$ & $1,246,808$ & $1,246,808$ & $1,246,808$ \\
\hline \multicolumn{9}{|c|}{ Prob Above Poverty (Without Taxes) } \\
\hline Reduced Form & Stimulus Eligible & $\begin{array}{c}0.007 * * * \\
(0.003)\end{array}$ & $\begin{array}{c}0.005 * * \\
(0.003)\end{array}$ & $\begin{array}{c}0.003 \\
(0.003)\end{array}$ & $\begin{array}{c}0.004 \\
(0.003)\end{array}$ & $\begin{array}{c}0.003 \\
(0.003)\end{array}$ & $\begin{array}{l}0.005^{*} \\
(0.003)\end{array}$ & $\begin{array}{c}0.006 * * \\
(0.003)\end{array}$ \\
\hline IV & Filed a 2007 Tax Return & $\begin{array}{c}0.336 * * \\
(0.131)\end{array}$ & $\begin{array}{c}0.277 * * \\
(0.129)\end{array}$ & $\begin{array}{c}0.171 \\
(0.128)\end{array}$ & $\begin{array}{c}0.185 \\
(0.130)\end{array}$ & $\begin{array}{c}0.158 \\
(0.130)\end{array}$ & $\begin{array}{l}0.234^{*} \\
(0.132)\end{array}$ & $\begin{array}{c}0.282 * * \\
(0.134)\end{array}$ \\
\hline Observations & & $1,246,808$ & $1,246,808$ & $1,246,808$ & $1,246,808$ & $1,246,808$ & $1,246,808$ & $1,246,808$ \\
\hline \multicolumn{9}{|c|}{ Prob Above Poverty (With Taxes) } \\
\hline Reduced Form & Stimulus Eligible & $\begin{array}{c}0.002 \\
(0.003)\end{array}$ & $\begin{array}{c}0.008 * * * \\
(0.003)\end{array}$ & $\begin{array}{c}0.006 * * \\
(0.003)\end{array}$ & $\begin{array}{c}0.003 \\
(0.003)\end{array}$ & $\begin{array}{c}0.008 * * * \\
(0.003)\end{array}$ & $\begin{array}{c}0.010 * * * \\
(0.003)\end{array}$ & $\begin{array}{c}0.007 * * * \\
(0.003)\end{array}$ \\
\hline IV & Filed a 2007 Tax Return & $\begin{array}{c}0.115 \\
(0.135)\end{array}$ & $\begin{array}{c}0.406 * * * \\
(0.142)\end{array}$ & $\begin{array}{l}0.329 * * \\
(0.145)\end{array}$ & $\begin{array}{c}0.167 \\
(0.143)\end{array}$ & $\begin{array}{c}0.388 * * * \\
(0.147)\end{array}$ & $\begin{array}{c}0.520 * * * \\
(0.154)\end{array}$ & $\begin{array}{c}0.382 * * * \\
(0.146)\end{array}$ \\
\hline Observations & & $1,246,808$ & $1,246,808$ & $1,246,808$ & $1,246,808$ & $1,246,808$ & $1,246,808$ & $1,246,808$ \\
\hline
\end{tabular}

Notes.-

The reduced form estimates show the impact of stimulus eligibility on the outcome variable. The IV estimates, where stimulus eligibility is used to instrument for filing a 2007 tax return, are reported only for the second stage. The first stage regression results (not shown) estimates the impact of stimulus eligibility on filing a 2007 tax return. Standard errors are in parentheses. Reduced form and IV are estimated using a $\$ 1500$ bandwidth. Eligibility for the stimulus is defined strictly by Form W-2 wages. The running variable is W-2 wages. The outcome wages is top coded to the 95 th percentile in each year. $* * * \mathrm{p}<0.01, * * \mathrm{p}<0.05, * \mathrm{p}<0.1$ 
Table A15: Effect of Filing a 2007 Tax Return on the Probability of Filing 2008-2014 Tax Returns, No Paid Tax Preparer Used in 2007

\begin{tabular}{lccccccc}
\hline \hline & 2008 & 2009 & 2010 & 2011 & 2012 & 2013 & 2014 \\
\hline Filed a 2007 Tax Return & 0.388 & 0.184 & 0.215 & 0.190 & 0.431 & $0.533^{*}$ & $0.431^{*}$ \\
& $(0.248)$ & $(0.239)$ & $(0.341)$ & $(0.324)$ & $(0.270)$ & $(0.310)$ & $(0.256)$ \\
& & & & & & & \\
Observations & $1,021,902$ & $1,021,902$ & $1,021,902$ & $1,021,902$ & $1,021,902$ & $1,021,902$ & $1,021,902$ \\
Bandwidth & 994.5 & 1127 & 766.3 & 819.6 & 995.9 & 875.3 & 1050 \\
\hline
\end{tabular}

Notes.-

The IV estimates, where stimulus eligibility is used to instrument for filing a 2007 tax return, are reported only for the second stage. The first stage regression results (not shown) estimates the impact of stimulus eligibility on filing a 2007 tax return. Standard errors are in parentheses. IV estimated using the optimal bandwidth selection approach by Calonico et al. (2016). Eligibility for the stimulus is defined strictly by Form W-2 wages. The running variable is W-2 wages. Regressions are restricted to individuals who did not use a paid tax preparer in 2007. This includes 2007 non-filers.

$* * * \mathrm{p}<0.01, * * \mathrm{p}<0.05, * \mathrm{p}<0.1$ 
Table A16: Impact of Filing on EITC Credit Amount

\begin{tabular}{|c|c|c|c|c|c|c|c|c|c|}
\hline & $\begin{array}{c}\text { Independent } \\
\text { Variable }\end{array}$ & $\begin{array}{c}2007 \\
(1) \\
\end{array}$ & $\begin{array}{c}2008 \\
(2)\end{array}$ & $\begin{array}{c}2009 \\
(3)\end{array}$ & $\begin{array}{c}2010 \\
(4)\end{array}$ & $\begin{array}{c}2011 \\
(5)\end{array}$ & $\begin{array}{c}2012 \\
(6) \\
\end{array}$ & $\begin{array}{c}2013 \\
(7)\end{array}$ & $\begin{array}{c}2014 \\
(8) \\
\end{array}$ \\
\hline Reduced Form & Stimulus Eligible & $\begin{array}{c}5.046 \\
(4.840)\end{array}$ & $\begin{array}{l}-1.398 \\
(8.488)\end{array}$ & $\begin{array}{c}2.203 \\
(8.189)\end{array}$ & $\begin{array}{c}0.721 \\
(8.599)\end{array}$ & $\begin{array}{c}5.289 \\
(9.021)\end{array}$ & $\begin{array}{c}9.306 \\
(9.940)\end{array}$ & $\begin{array}{l}10.071 \\
(9.528)\end{array}$ & $\begin{array}{l}12.256 \\
(9.092)\end{array}$ \\
\hline Bandwidth & & 1256 & 861.2 & 1137 & 1072 & 962.8 & 783.5 & 868.5 & 906.6 \\
\hline IV & Filed a 2007 Tax Return & $\begin{array}{c}-8.807 \\
(281.591)\end{array}$ & $\begin{array}{c}-56.803 \\
(382.721)\end{array}$ & $\begin{array}{c}95.925 \\
(386.521)\end{array}$ & $\begin{array}{c}33.524 \\
(394.194)\end{array}$ & $\begin{array}{c}250.307 \\
(408.256)\end{array}$ & $\begin{array}{c}395.882 \\
(417.536)\end{array}$ & $\begin{array}{c}480.509 \\
(396.345)\end{array}$ & $\begin{array}{c}572.291 \\
(394.109)\end{array}$ \\
\hline Observations & & $1,246,808$ & $1,246,808$ & $1,246,808$ & $1,246,808$ & $1,246,808$ & $1,246,808$ & $1,246,808$ & $1,246,808$ \\
\hline Bandwidth & & 763.6 & 898.6 & 1061 & 1074 & 942.0 & 899.1 & 1022 & 985.1 \\
\hline
\end{tabular}

Notes.-

The reduced form estimates show the impact of stimulus eligibility on the outcome variable. The IV estimates, where stimulus eligibility is used to instrument for filing a 2007 tax return, are reported only for the second stage. The first stage regression results (not shown) estimates the impact of stimulus eligibility on filing a 2007 tax return. Standard errors are in parentheses. Reduced form and IV are estimated using the optimal bandwidth selection approach by Calonico et al. (2016). Eligibility for the stimulus is defined strictly by Form W-2 wages. The running variable is W-2 wages.

$* * * \mathrm{p}<0.01, * * \mathrm{p}<0.05, * \mathrm{p}<0.1$ 
Table A17: Impact of Filing in 2007 on Outcomes Using Unrestricted Sample

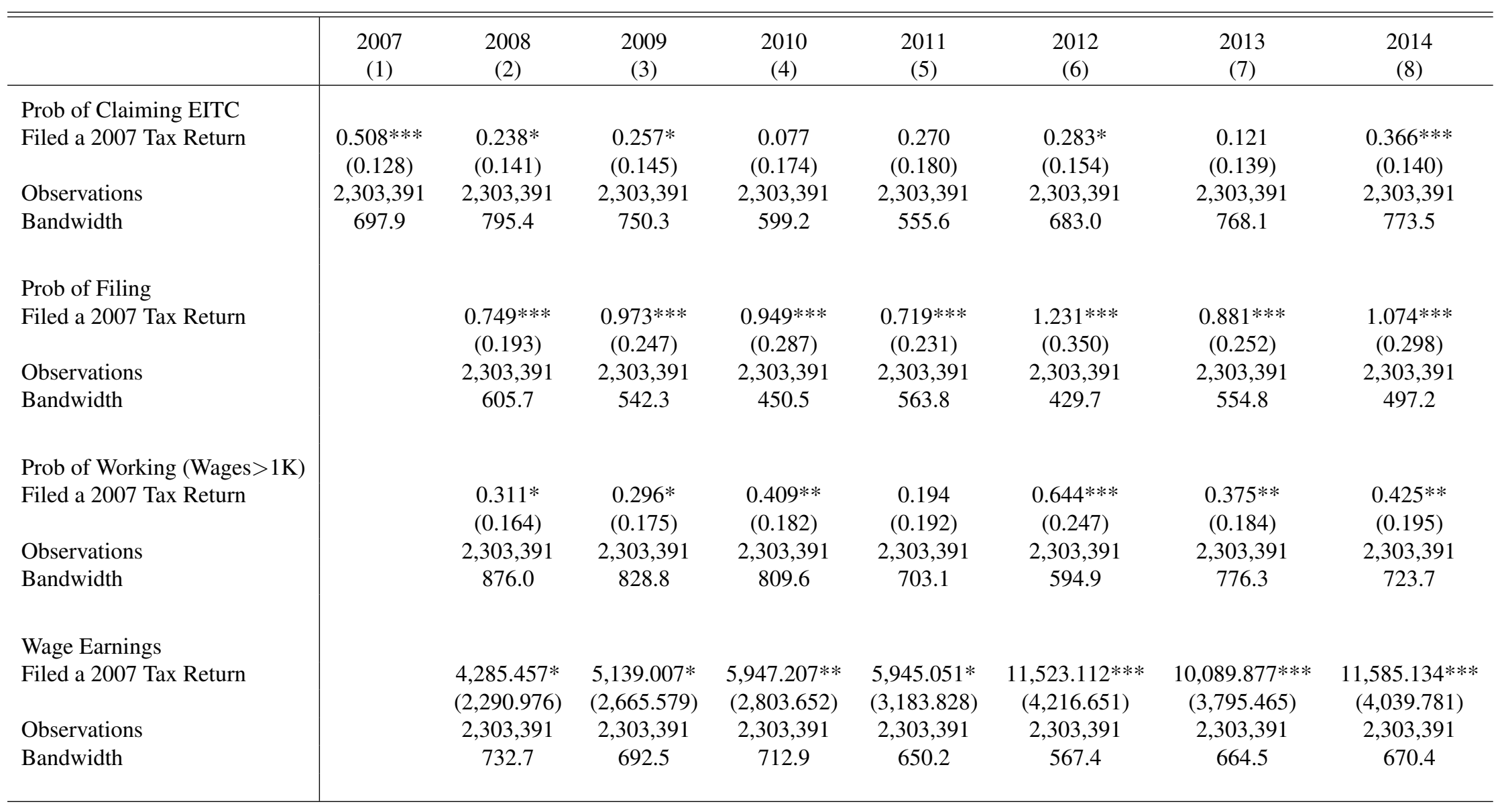

Notes.-

The IV estimates, where stimulus eligibility is used to instrument for filing a 2007 tax return, are reported only for the second stage. The first stage regression results (not shown) estimates the impact of stimulus eligibility on filing a 2007 tax return. Standard errors are in parentheses. Reduced form and IV are estimated using the optimal bandwidth selection approach by Calonico et al. (2016). Eligibility for the stimulus is defined strictly by Form W-2 wages. The running variable is W-2 wages. The outcome wages is top coded to the 95th percentile in each year. The sample is restricted to the sample of workers with wages below $\$ 6,000$ and aged 25-60 in 2005 .

$* * * \mathrm{p}<0.01, * * \mathrm{p}<0.05, * \mathrm{p}<0.1$ 
Table A18: Placebo Test Dropping Mass Point At and Near \$3,000

\begin{tabular}{|c|c|c|c|c|}
\hline & All & Drop Wages $=\$ 3,000$ & Drop Wages $=\$ 2900-\$ 3100$ & Drop Wages $=\$ 2800-\$ 3200$ \\
\hline \multirow[t]{2}{*}{ Stimulus Eligibility } & $0.021 * * *$ & $0.018 * * *$ & $0.021 * * *$ & $0.020 * * *$ \\
\hline & $(0.004)$ & $(0.004)$ & $(0.004)$ & $(0.005)$ \\
\hline Observations & 323,910 & 322,265 & 291,701 & 259,905 \\
\hline Bandwidth & 1000 & 1000 & 1000 & 1000 \\
\hline
\end{tabular}

Notes.-

The reduced form estimates show the impact of stimulus eligibility on the outcome variable. Estimates are derived using weighted least squares with triangle weights. Eligibility for the stimulus is defined strictly by Form W-2 wages. The running variable is $2006 \mathrm{~W}-2$ wages.

$* * * \mathrm{p}<0.01, * * \mathrm{p}<0.05, * \mathrm{p}<0.1$ 
Figure A1: Mean Outcomes Using \$2,000 Threshold

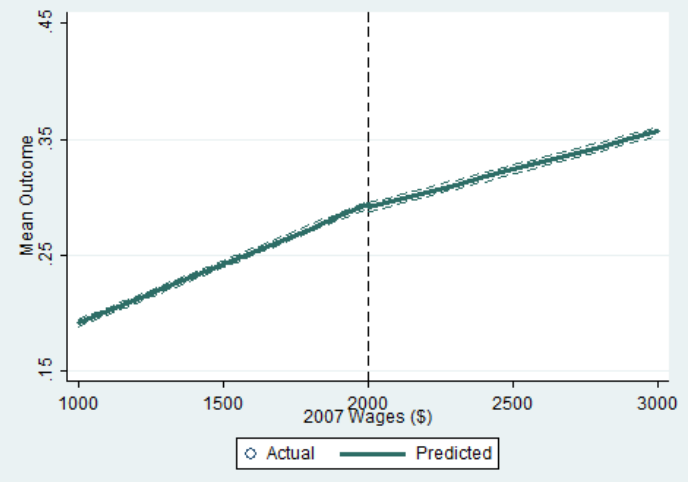

(a) Claim EITC, 2007

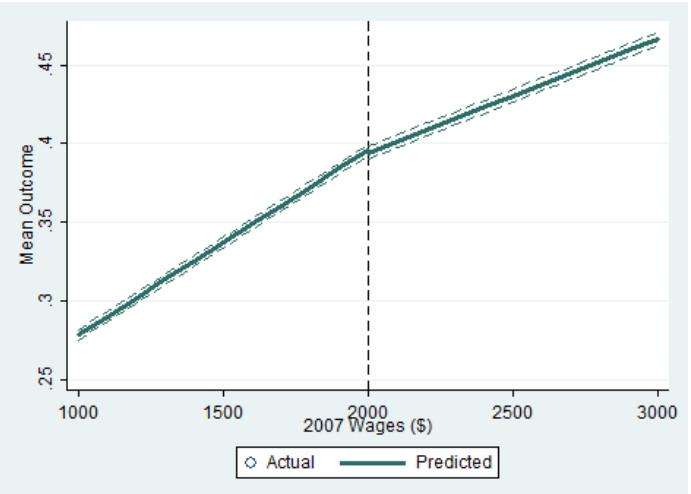

(c) File, 2007

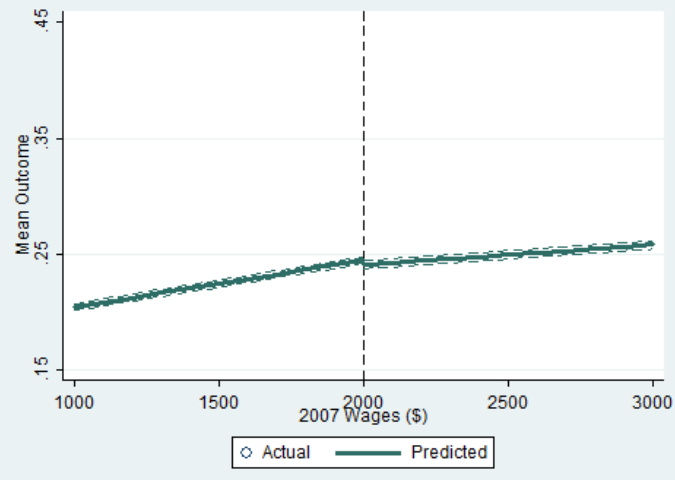

(b) Claim EITC, 2008

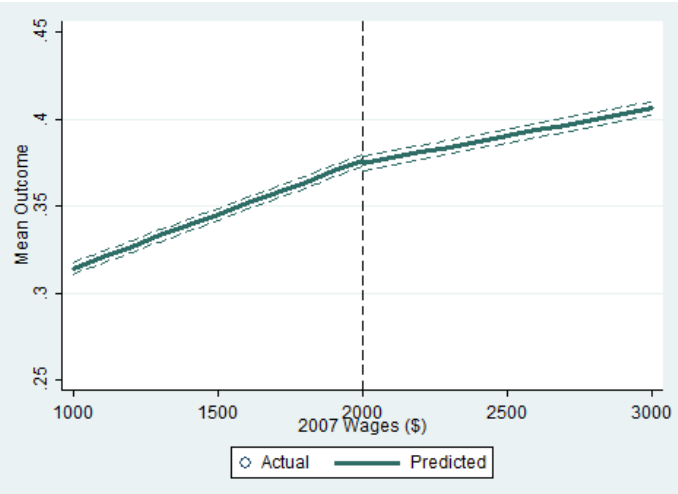

(d) File, 2008

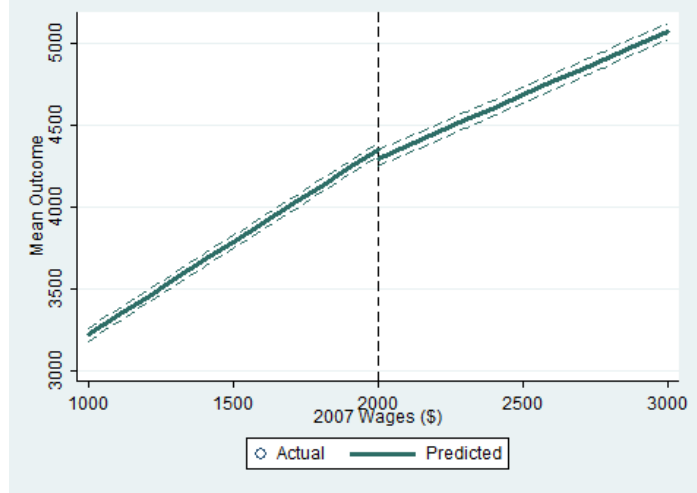

(e) Wage Earnings, 2008

Notes.-

Estimates are derived using weighted least squares with triangle weights. The predicted estimates are the solid lines and the standard errors are the dashed lines. The circles represent the mean outcome in $\$ 100$ bins of $2007 \mathrm{~W}-2$ wages. Wage earnings to the 95th percentile. 
Figure A2: Mean Outcomes Using \$4,000 Threshold

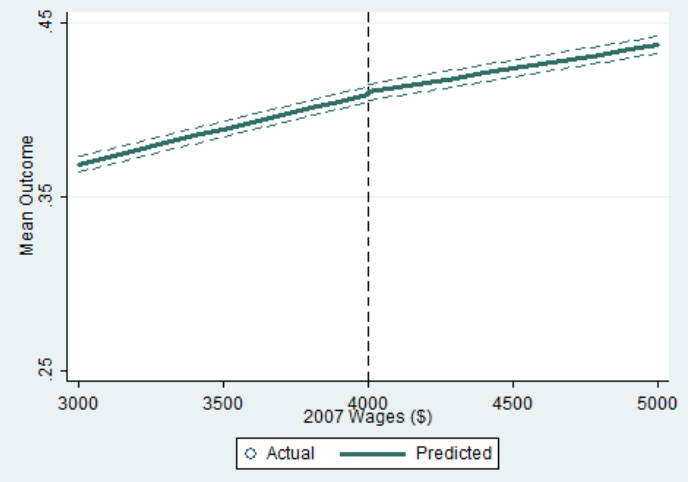

(a) Claim EITC, 2007

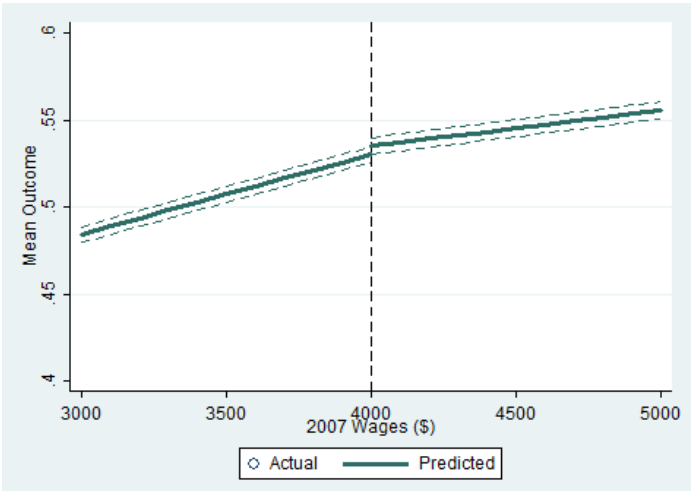

(c) File, 2007

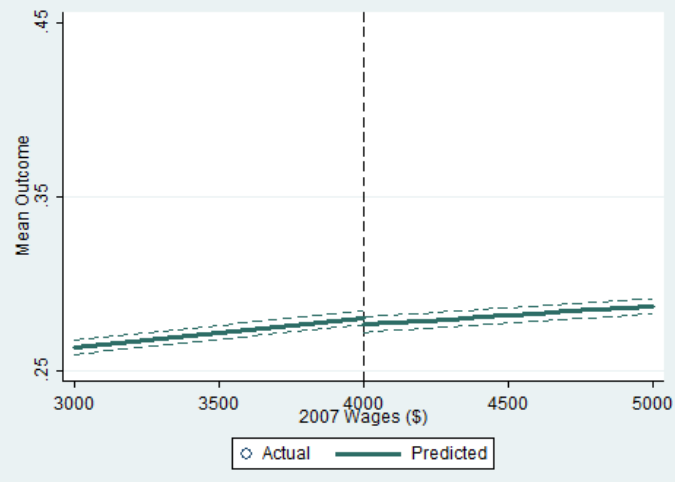

(b) Claim EITC, 2008

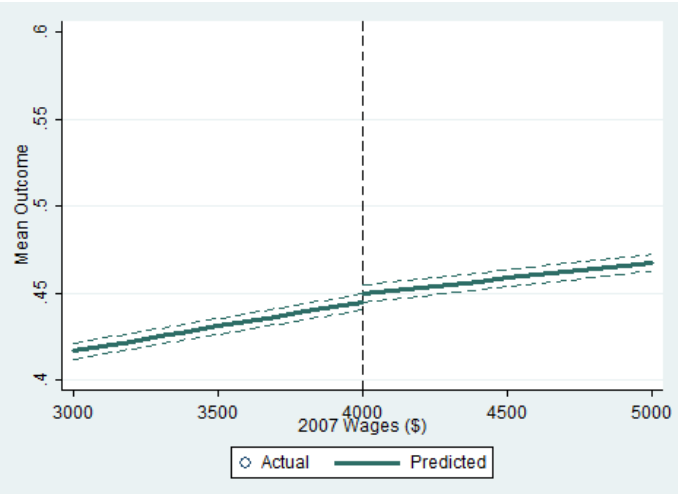

(d) File, 2008

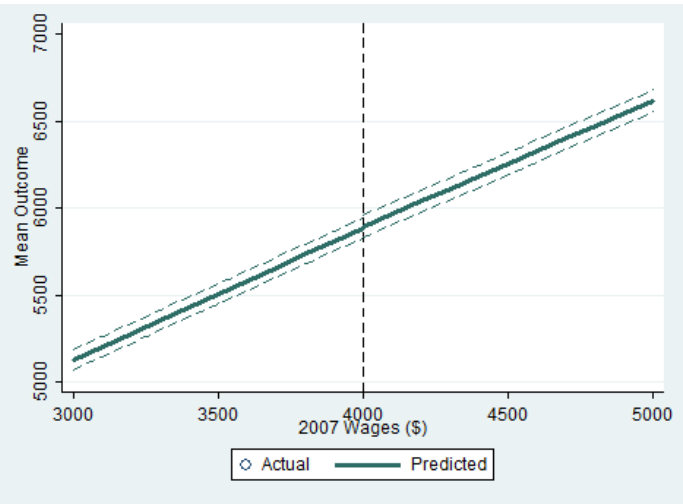

(e) Wage Earnings, 2008

Notes.-

Estimates are derived using weighted least squares with triangle weights. The predicted estimates are the solid lines and the standard errors are the dashed lines. The circles represent the mean outcome in $\$ 100$ bins of $2007 \mathrm{~W}-2$ wages. Wage earnings to the 95th percentile. 
Figure A3: Mean Outcomes Using 2006 Wage Earnings as the Running Variable

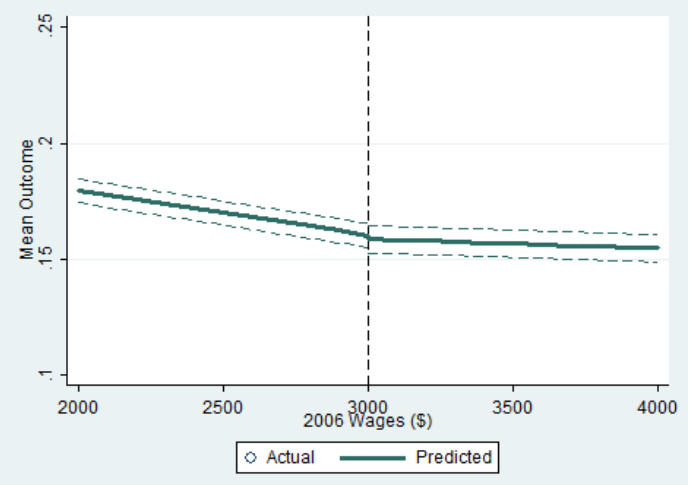

(a) Claim EITC, 2007

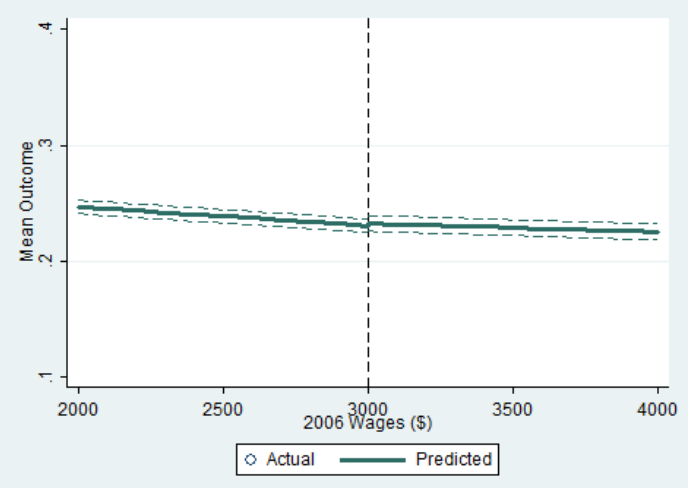

(c) File, 2007

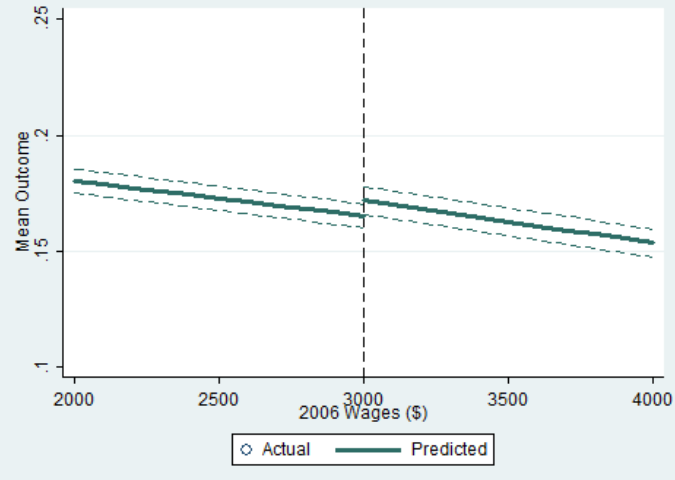

(b) Claim EITC, 2008

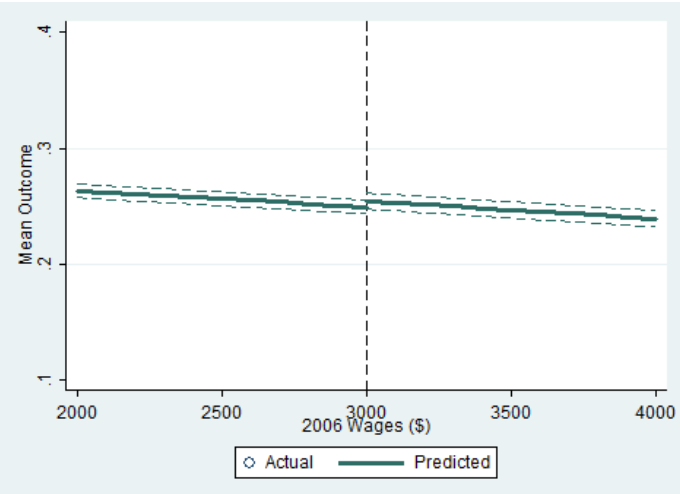

(d) File, 2008

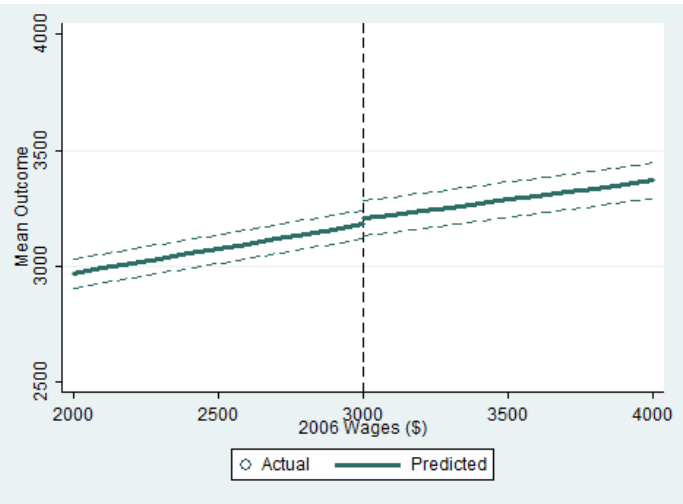

(e) Wage Earnings, 2008

Notes.-

Estimates are derived using weighted least squares with triangle weights. The predicted estimates are the solid lines and the standard errors are the dashed lines. The circles represent the mean outcome in $\$ 100$ bins of $2006 \mathrm{~W}-2$ wages. Wage earnings to the 95th percentile. 
Figure A4: Placebo Test Using 2003 and 2004 Non-Filers, Mean Outcomes

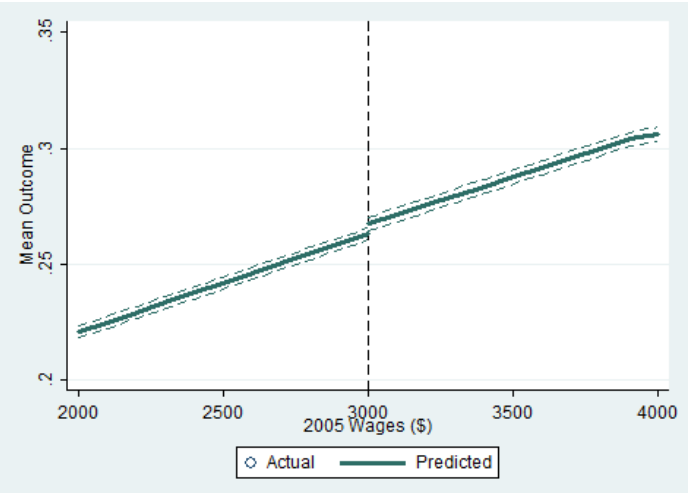

(a) Claim EITC, 2005

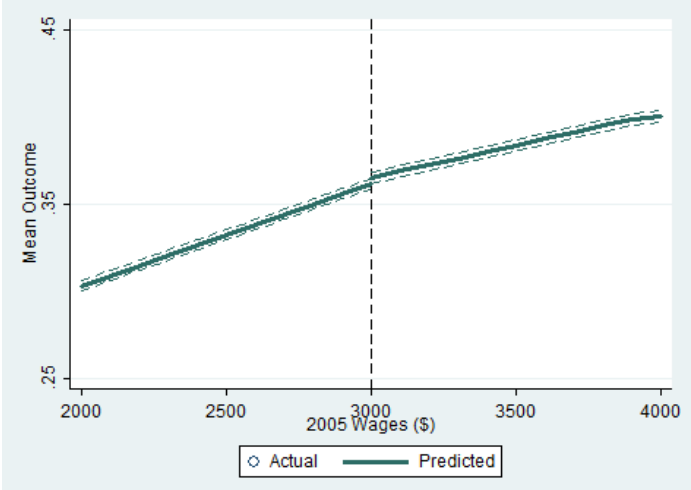

(c) File, 2005

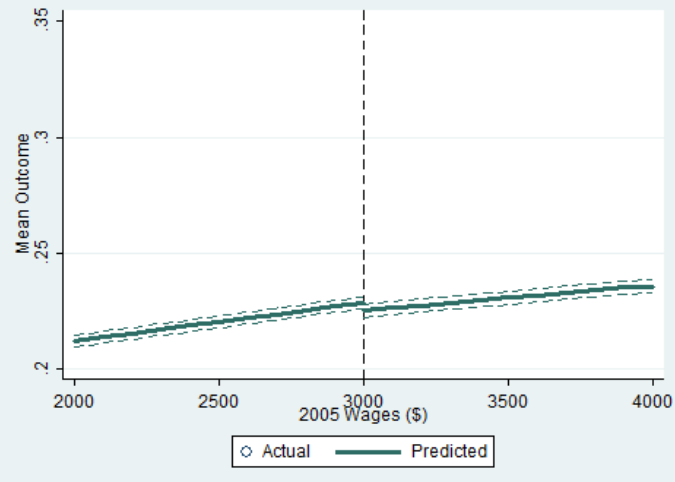

(b) Claim EITC, 2006

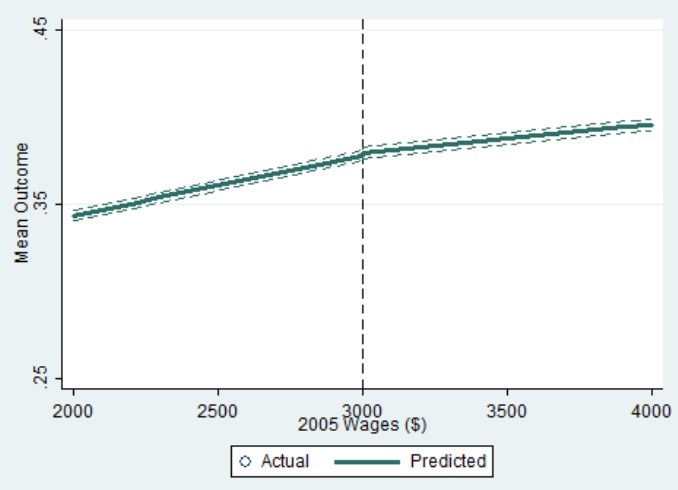

(d) File, 2006

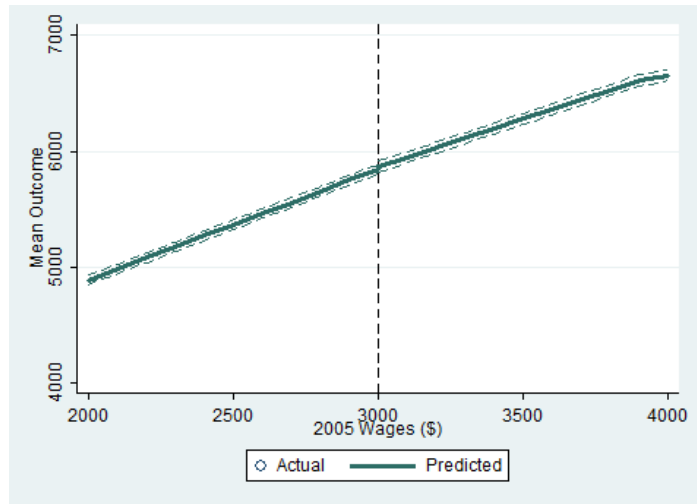

(e) Wage Earnings, 2006

Notes.-

Estimates are derived using weighted least squares with triangle weights. The predicted estimates are the solid lines and the standard errors are the dashed lines. The circles represent the mean outcome in $\$ 100$ bins of $2005 \mathrm{~W}-2$ wages. Wage earnings to the 95th percentile. Sample consists of 2003 and 2004 non-filers aged 25-60 in 2003 with social security numbers who were not claimed as dependents. 